\title{
Characteristics of Early Cretaceous wildfires in peat-forming environment, NE China
}

\author{
Shuai Wang, Long-Yi Shao*, Zhi-Ming Yan, Ming-Jian Shi and Yun-He Zhang
}

\begin{abstract}
Inertinite maceral compositions in coals from the Early Cretaceous Erlian, Hailar, and Sanjiang Basins in NE China are analyzed in order to reveal palaeowildfire events and palaeoclimate variations. Although huminite is the dominant maceral group in the studied basins, the inertinite group, as a byproduct of palaeowildfires, makes up a considerable proportion. Occurrence of inertinite macerals indicates that wildfires were widespread and frequent, and supports the opinion that the Early Cretaceous was a "high-fire" interval. Inertinite contents vary from $0.2 \%$ to $85.0 \%$, mostly within the range of $10 \%-45 \%$, and a model-based calculation suggests that the atmospheric oxygen levels during the Aptian and Albian (Early Cretaceous) were around $24.7 \%$ and $25.3 \%$ respectively. Frequent fire activity during Early Cretaceous has been previously related to higher atmospheric oxygen concentrations. The inertinite reflectance, ranging from $0.58 \% R$ o to $2.00 \% R$, indicates that the palaeowildfire in the Early Cretaceous was dominated by ground fires, partially reaching-surface fires. These results further support that the Cretaceous earliest angiosperms from NE China were growing in elevated $\mathrm{O}_{2}$ conditions compared to the present day.
\end{abstract}

Keywords: Inertinite, Coal, Wildfire, Palaeo-atmospheric oxygen level, Angiosperm, Early Cretaceous, NE China

\section{Introduction}

As a byproduct of peatland evolution under the common influence of geological conditions including palaeoclimate, palaeobotany, palaeogeography and palaeotectonics, coal is not only an important energy resource, but also a sediment sensitive to environmental changes in deep geological time (Shao et al. 2012). Therefore, the maceral compositions of coal can record subtle changes in depositional conditions and palaeoclimate (Petersen and Ratanasthien 2011; Petersen and Lindström 2012).

Almost all coal macerals in the inertinite group have been identified as incompletely combusted charcoal and are closely tied to wildfires in peatlands (Scott 2000, 2010; Scott and Stea 2002; Scott and Glasspool 2006, 2007; Glasspool and Scott 2010; Hudspith et al. 2012; Zhang et al. 2016). The occurrence of wildfire needs sufficient temperature, fuel and oxygen conditions (Brown et al. 2012). Charcoal, as the byproduct of wildfire, is first recorded in the latest Silurian and has subsequently been found in all geological periods from different depositional environments (Jones and Chaloner 1991; Glasspool et al.

\footnotetext{
* Correspondence: shaol@cumtb.edu.cn

College of Geoscience and Surveying Engineering, China University of Mining and Technology (Beijing), Beijing 100083, China
}

2004; Bowman et al. 2009). The minimum oxygen content that can support combustion in nature is $15 \%$ (Belcher and McElwain 2008). Wildfire plays an important role in many ecosystems, which not only affects the emission of atmospheric carbon dioxide and aerosols, but also plays an important controlling role in the distribution and evolution of the biological community (Scott and Stea 2002; Bowman et al. 2009; Scott 2010). The inertinite content in coal or other sediments is related to atmospheric oxygen levels, and thus can be used in interpretation of the palaeoenvironment of peatlands (Scott and Glasspool 2006; Diessel 2010; Glasspool and Scott 2010; Zhan et al. 2011; Shao et al. 2012; Glasspool et al. 2015).

The Cretaceous is an important coal-forming period in geological history (Han and Yang 1980) and is characterized by global greenhouse climates (Hu et al. 2012; Wang 2013). Coal seams of this period are widely distributed around the world (Brown et al. 2012). Previous research on wildfires in coal mainly investigated coals in the northern hemisphere (North America, Europe, India, and Asia) (Uhl and Kerp 2003; Hamad et al. 2016; Jasper et al. 2017). Wildfires were widespread and frequent during large parts of the Cretaceous, and thus the Cretaceous has been considered as a high frequency interval of wildfires in Earth's 
history (Bond and Scott 2010; Diessel 2010; Brown et al. 2012). It is believed that the frequent occurrence of fire events is related to the abundance of gymnosperms and the emergence of angiosperms (Bond and Scott 2010; Brown et al. 2012). Although many studies have discussed the coal-forming environment and coal petrology of the Early Cretaceous coals of NE China, few studies focus on the palaeoclimate significance based on the fire-derived inertinites (Xu 2011; Zhang et al. 2014). Therefore, in this study, Early Cretaceous coals in the Erlian, Hailar and Sanjiang Basins of NE China are selected to assess the characteristics of wildfire types and atmospheric oxygen levels. The work provides further insight into the occurrences of wildfires and palaeoenvironmental changes during this period.

\section{Geological setting}

Northeastern China is located at the eastern part of the Central Asian Orogenic Belt (Wu et al. 2011), which experienced two stages of tectonic evolution under different tectonic regimes. During the Paleozoic, tectonic development was controlled by the evolution of the PalaeoAsian Ocean between Siberia and North China cratons, but since Jurassic, it was dominated by the subduction of Palaeo-Asian Ocean and the collision of MongoliaOkhotsk suture (Wang et al. 2007; Wu et al. 2011). The latter tectonic regime fundamentally changed the tectonic framework of NE China and initiated NE- to NNE-oriented tectonic zones (Li 1988), which resulted in the development of a series of Late Jurassic to Early Cretaceous NE- to NNE-oriented faulted coal-bearing basins.

NE China includes Heilongjiang, Jilin and Liaoning Provinces and the eastern part of Inner Mongolia Autonomous Region with a vast area of roughly 1.6 million $\mathrm{km}^{2}$ (Shao et al. 2013). Tectonically, the region consists of Hailar Basin and Erlian Basin in the west, Songliao Basin in the center, and Sanjiang Basin in the east (Fig. 1), respectively. The faulted basins in NE China are

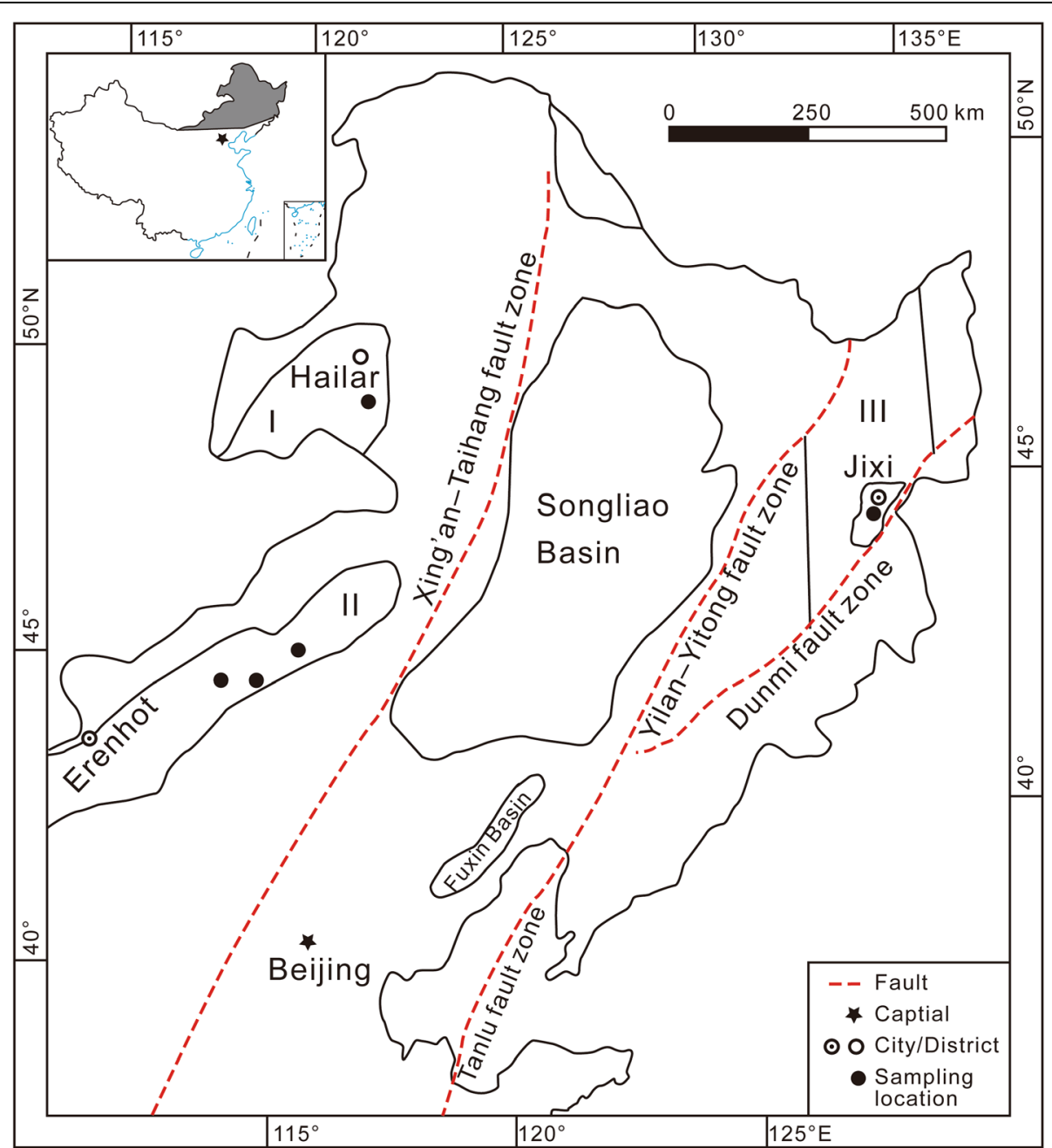

Fig. 1 Outline map showing the Early Cretaceous sedimentary basins of NE China (modified from Sha 2007). The inset map of China is modified after the National Bureau of Surveying and Mapping of China (No. GS(2016)1603). I - Hailar Basin; II - Erlian Basin; III - Sanjiang Basin 
filled by Lower Cretaceous coal measures, mostly continental clastics, including conglomerate, sandstone, siltstone, mudstone and coal, from $1000 \mathrm{~m}$ to $3000 \mathrm{~m}$ in thickness (Li 1988), formed mainly in continental environments. Lower Cretaceous successions are unconformably overlain by Upper Cretaceous sedimentary rocks, and unconformably underlain by the Upper Jurassic (Shao et al. 2013).

The Hailar Basin consists of up to $6 \mathrm{~km}$ of Upper Mesozoic-Cenozoic continental sediments and forms a NE-trending basin together with the adjacent Tamtsag Basin in Mongolia to the south (Gao et al. 2009; Guo et al. 2018). The Erlian Basin is a Mesozoic-Cenozoic intra-continental faulted basin, developed on Hercynian folded basement, which is located in the suture between the Asian and Siberian Plates (Zhu et al. 2000). The Sanjiang Basin is an important Mesozoic coal-bearing basin, which is located in the Jiamusi Massif of the eastern Heilongjiang Province (Yang et al. 2005).

From bottom to top, the lithostratigraphic units of the Lower Cretaceous coal measures include the Aershan, Tengger and Saihantala Formations in the Erlian Basin; Tongbomiao, Nantun, Damoguaihe and Yimin Formations in the Hailar Basin; and Didao, Chengzihe and Muling Formations in the Sanjiang Basin, respectively (Fig. 2). Chronostratigraphically, they correspond to the Aptian and most of the Albian, Early Cretaceous (Sun and Zheng 2000; Zhang et al. 2015; ICS 2017) (Fig. 2).

\section{Sampling and methodology}

The studied coal samples were collected from: (1) coal mines in the Saihantala Formation of the Jiergalangtu, Baiyinhua, and Chaokewula sags in the Erlian Basin; (2) the Yimin Formation of the Yimin sag in the Hailar Basin; and (3) the Chengzihe Formation of Jixi mine area in the Sanjiang Basin (Fig. 3), comprising 19, 12, and 5 samples, respectively. All the collected samples were stored immediately in plastic bags to ensure as little contamination or oxidation as possible. Samples were analyzed in the State Key Laboratory of Coal Resources and Safe Mining, Beijing, China. The maceral content was determined by point counting, and huminite and inertinite reflectance measurements were carried out on most samples. The coal petrographic analyses were made according to conventional procedures (ICCP 2001; Sýkorová et al. 2005).

Coal samples were crushed to less than $1 \mathrm{~mm}$ diameter to make polished blocks for microscopic observation. Maceral analyses, as well as huminite and inertinite reflectance measurements were made on polished blocks under reflected white and fluorescent light, with $50 \times$ oil immersion objectives using a Leica DM4500P LED microscope. For the maceral analyses, a total of 500 valid points in each polished block were counted. For the reflectance measurements, an immersion oil with a refractive index of 1.518 and YAG $(0.903 \% R o)$, GGG $(1.719 \% R o)$, sapphire
$(0.590 \% R o)$, and optically black (zero) standards at $23{ }^{\circ} \mathrm{C}$ were used, and a total of 100 valid points in each polished block were counted. Finally, the testing results are converted into percentage of each maceral and average reflectance value in the total valid points. For observation of the homogenization status of cell walls, macerals were observed under scanning electron microscopy.

\section{Results}

\subsection{Maceral compositions}

Table 1 shows the maceral and mineral matter distributions of the samples collected from the three basins studied.

In the Erlian Basin, huminite is the most dominant maceral group (14.4\%-99.3\%) with an average value of $63.1 \%$, but a few samples exhibit higher values of inertinite and liptinite contents as well (Table 1). The inertinite content of all samples varies between $0.2 \%$ and $85.0 \%$ with an average value of $33.9 \%$. Liptinite is not commonly observed, the content of which ranges between $0.2 \%$ and $15.0 \%$ with an average value of $3.0 \%$. Fusinite, semifusinite and inertodetrinite are the abundant inertinite macerals with average content at $13.4 \%, 8.1 \%, 11.3 \%$, respectively. Funginite, macrinite and micrinite are rarely found in the samples. The minerals comprise $0.8 \%-17.7 \%$ with an average value of $4.9 \%$.

In the Hailar Basin, it is noted that huminite and inertinite are the dominant maceral groups, followed by mineral components, while liptinite is rare (Table 1). The huminite group is $81.5 \%$ in average of the total macerals, ranging from $40.2 \%$ to $95.6 \%$, the inertinite group $18.6 \%$ in average, ranging from $4.4 \%$ to $59.8 \%$, and the mineral components are $1.3 \%$ in average. Fusinite and semifusinite are the abundant inertinite macerals with average content at $17.8 \%$ and $0.7 \%$, respectively.

In the Sanjiang Basin, the huminite is also the dominant group, ranging from $74.9 \%$ to $92.0 \%$, with an average value of $87 \%$, while the inertinite group accounts for $9.8 \%$ in average, ranging from $2.7 \%$ to $24.3 \%$ (Table 1 ). The liptinite is $3.2 \%$ in average and the mineral components are $0.4 \%$ in average. Fusinite and semifusinite are the major inertinite macerals with average content at $6.2 \%$ and $3.6 \%$, respectively.

\subsection{Inertinite reflectance values}

Since inertinite reflectance is affected by combustion temperature, the temperature of wildfire combustion can be inferred by measuring the inertinite reflectance (Petersen and Lindström 2012). Although there is no completely linear relationship between inertinite reflectance and burning temperature, it can be described by the linear regression eq. $T=184.10+117.76 \times \%$ Ro (coefficient of determination $r^{2}=0.91$ ), where $T$ is the combustion temperature and \%Ro is the measured inertinite reflectance (Jones 1997). 


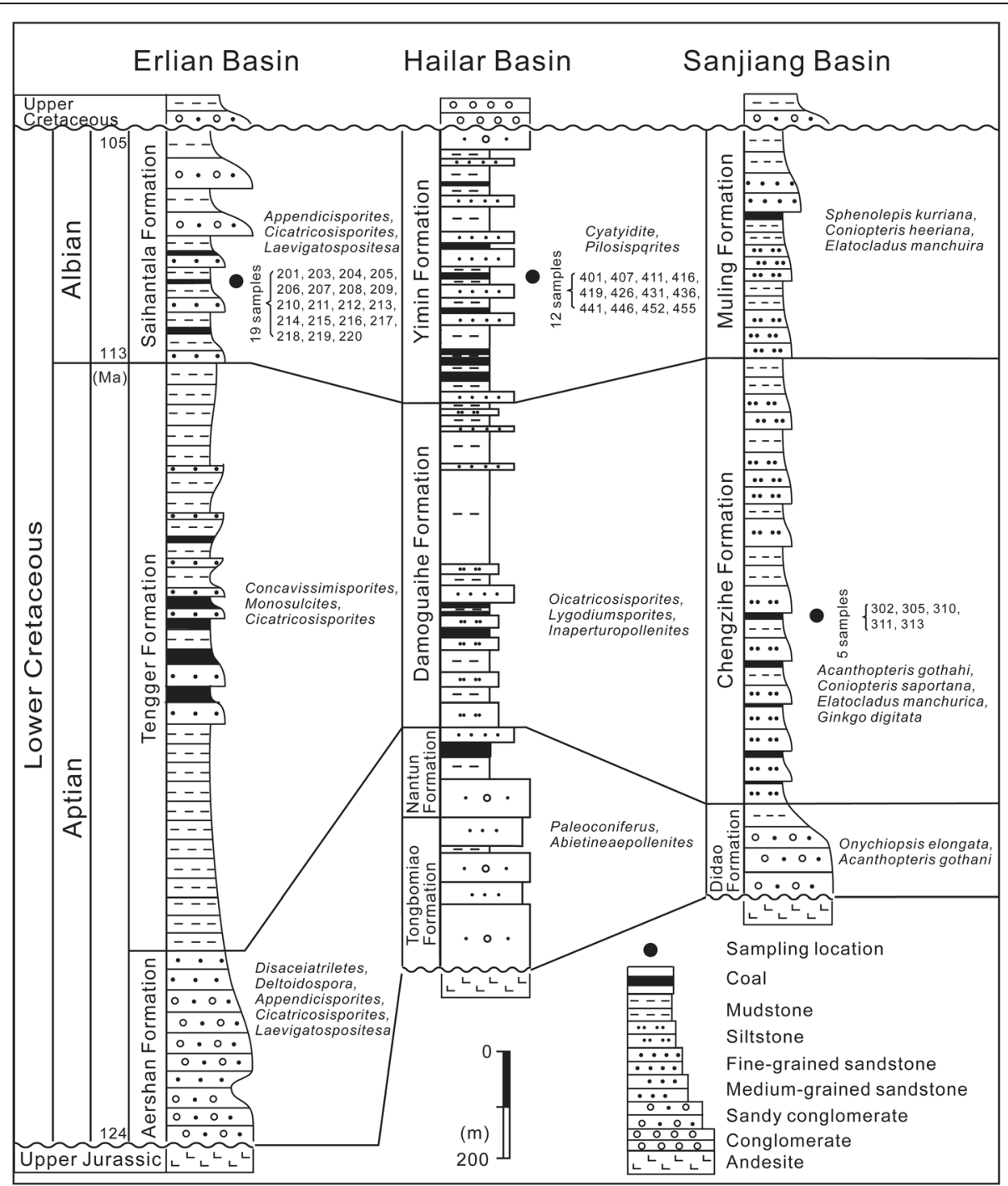

Fig. 2 Columnar sections showing lithology and coal seams of the Lower Cretaceous coal measures in the Erlian, Hailar and Sanjiang Basins. The palynological data are based on Heilongjiang Bureau of Geology and Mineral Resources (1993), Zhang and Long (1995) and Zhu et al. (2000)

The measured inertinite reflectance results are shown in Table 2, from which it can be seen that inertinite reflectance in the Erlian Basin is $0.59 \% R o-2.00 \%$ Ro with an average of $1.03 \% R o$; inertinite reflectance in the Hailar Basin is $0.58 \% R o-0.90 \% R o$, with an average value of $0.75 \% R o$; and the Sanjiang Basin inertinite reflectance of $0.94 \% R o-1.24 \% R o$, with an average value of $1.05 \% R o$. Based on the relationship between inertinite reflectance and combustion temperature (Jones 1997), the wildfire combustion temperature for the studied sections in NE China was calculated (Table 2). The combustion temperature of wildfire in the Erlian Basin is 253.58$419.62{ }^{\circ} \mathrm{C}$ with an average value of $305.34{ }^{\circ} \mathrm{C}$; the wildfire combustion temperature in the Hailar Basin is $252.40-290.08^{\circ} \mathrm{C}$ with an average value of $271.83^{\circ} \mathrm{C}$; and the wildfire combustion temperature in the
Sanjiang Basin is $294.79-330.12^{\circ} \mathrm{C}$ with an average value of $308.22^{\circ} \mathrm{C}$.

\section{Discussion}

\subsection{Inertinite macerals: wildfire implications}

A mix of inertinite particle sizes from more than $500 \mu \mathrm{m}$ to less than $10 \mu \mathrm{m}$ could be observed in polished blocks, which recorded local wildfire activity and regional activity (Scott and Glasspool 2007; Robson et al. 2015). The common characteristics of inertinite are the relatively high reflectivity (Fig. 3). Fusinite, semifusinite, and inertodetrinite are the most common inertinite macerals (Fig. 3a-c, e). Fusinite and semifusinite have open cellular structure and homogenized cell walls (Fig. 4). Comparatively, semifusinite has lower reflectivity than fusinite (Fig. 3e). Rare inertinite in areas indicates that 

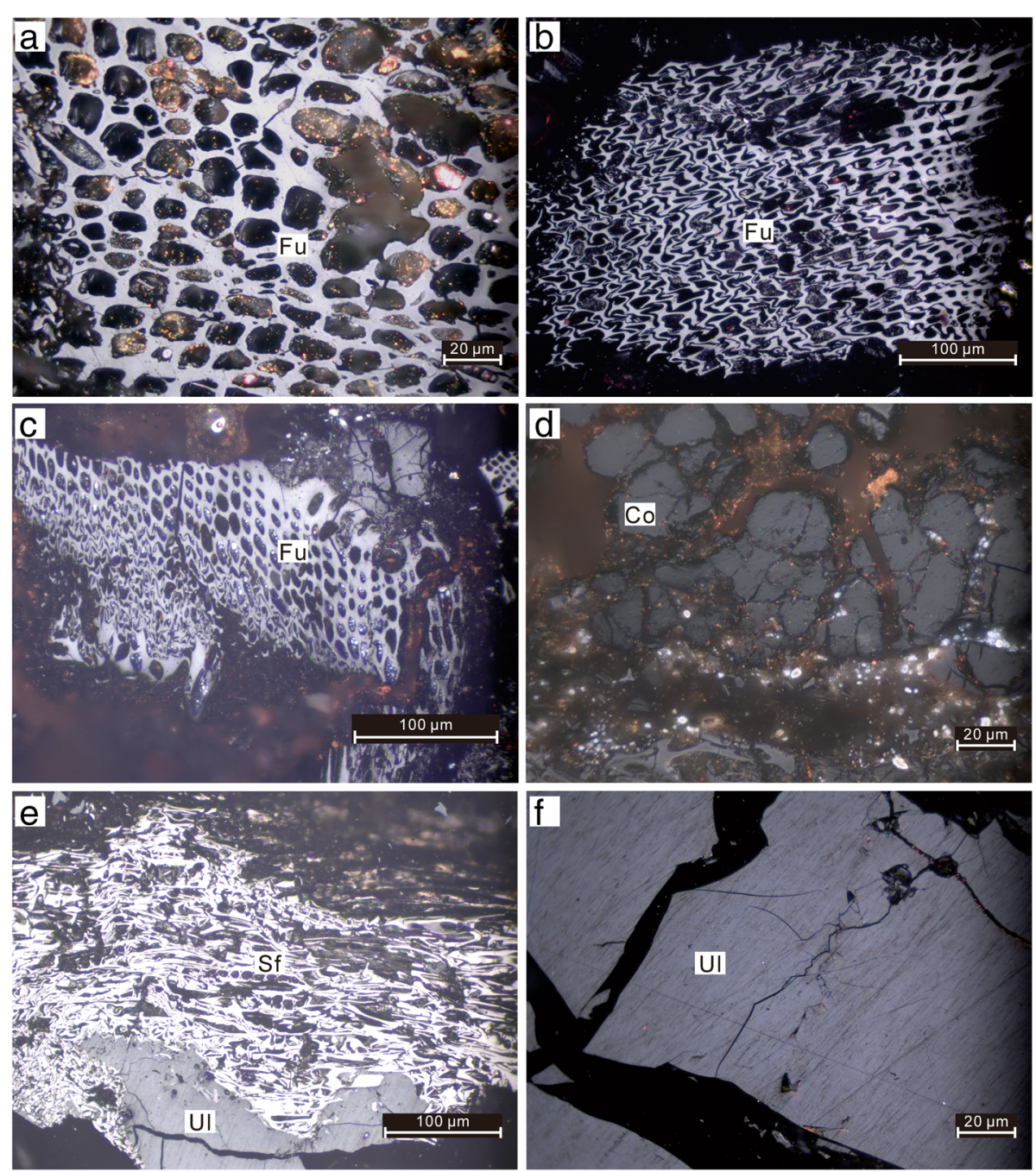

Fig. 3 Photomicrographs of typical coal macerals in the studied coals. Inertinite shows higher reflectivity than huminite. Huminite maceral group: ulminite and corpohuminite. Inertinite maceral group: fusinite, semifusinite and Inertodetrinite. Oil immersion, white light. a, b Distinct cellular structure is preserved in the fusinite (Fu); from sample 407, Hailar Basin; c d Fusinite (Fu) with distinct cellular structure and corpohuminite (Co) with spherical or oval shape indicating resistance to decay; from sample 419, Hailar Basin; e Semifusinite (Sf) with brittle fractures has contacts with ulminite (UI); from sample 302, Sanjiang Basin; f Due to homogenization, structures within the cell walls are not visible in the ulminite (UI); from sample 211, Erlian Basin

fuel would have accumulated between periods of fire activity (Robson et al. 2015).

Enrichment of inertinite in Lower Cretaceous coals is very common in the studied area. The coals in the western part of the study area contain higher charcoal abundances than those in the eastern part based on the coal petrological evidence (Table 1). Higher levels of inertinite in contemporaneous coals have also been recorded from New Zealand, America, Canada, Africa, and North China (Diessel 2010; Sun et al. 2017). The variability in inertinite content indicates that wildfires were prevalent in the coal-forming peatland during the Early Cretaceous, and may record transitional periods from higher wildfire activity (Erlian Basin and
Hailar Basin) to lower wildfire activity (Sanjiang Basin).

\subsection{Fire types}

According to different temperature and fuel, wildfires can be subdivided into three categories (Scott 1989; Scott and Jones 1994; Scott 2000), namely: (1) ground fires that burn organic material below litter, producing temperatures of around $400^{\circ} \mathrm{C}$; (2) surface fires that burn litter and herbaceous and shrubby plants, producing temperatures of around $600^{\circ} \mathrm{C}$; and (3) crown fire that burn the canopy of trees and lager shrubs, producing temperatures of $800{ }^{\circ} \mathrm{C}$ or higher. Based on the calculated burning temperature, we have summarized 


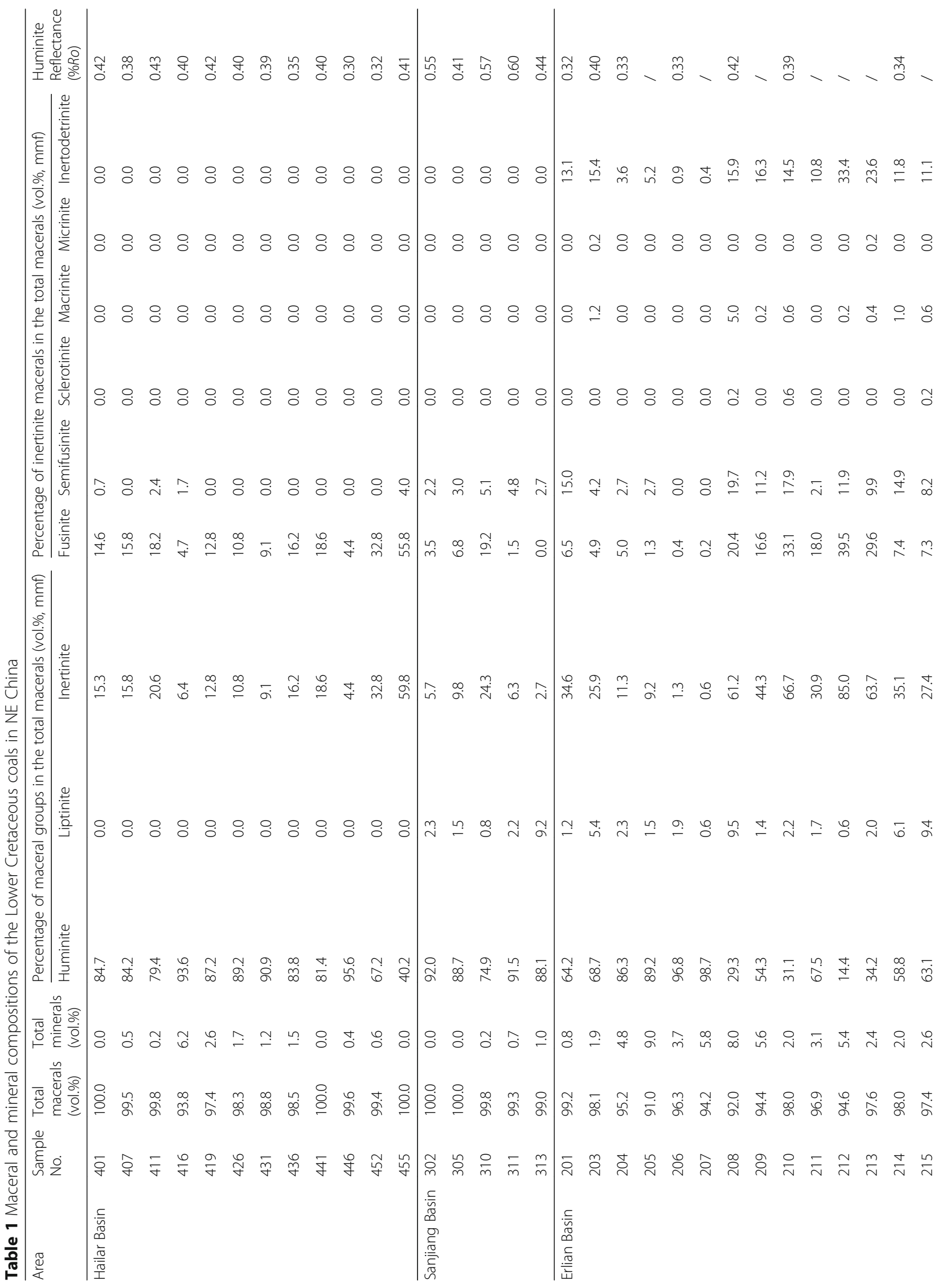




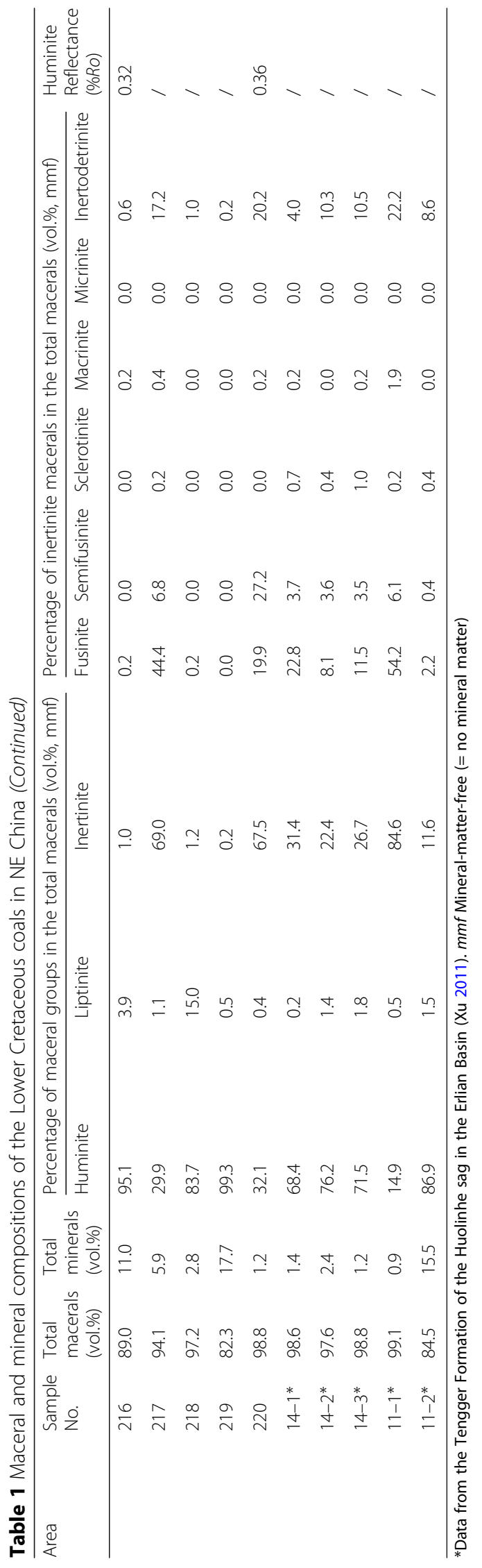


Table 2 Measured inertinite reflectance and inferred burning temperatures of wildfire in the Lower Cretaceous coals, NE China

\begin{tabular}{|c|c|c|c|c|c|c|}
\hline \multirow[t]{2}{*}{ Area } & \multirow[t]{2}{*}{ Sample No. } & \multirow[t]{2}{*}{ Effective points } & \multicolumn{3}{|c|}{ Measured inertinite reflectance (\%Ro) } & \multirow{2}{*}{$\begin{array}{l}\text { Inferred burning } \\
\text { temperature } T^{* *}\left({ }^{\circ} \mathrm{C}\right.\end{array}$} \\
\hline & & & Minimum & Maximum & Average & \\
\hline \multirow[t]{12}{*}{ Hailar Basin } & 401 & 100 & 0.42 & 2.06 & 0.88 & 287.73 \\
\hline & 407 & 101 & 0.51 & 1.60 & 0.77 & 274.78 \\
\hline & 411 & 100 & 0.51 & 2.07 & 0.80 & 278.31 \\
\hline & 416 & 101 & 0.44 & 1.43 & 0.90 & 290.08 \\
\hline & 419 & 107 & 0.22 & 1.82 & 0.72 & 268.89 \\
\hline & 426 & 101 & 0.47 & 0.99 & 0.73 & 270.06 \\
\hline & 431 & 100 & 0.43 & 1.25 & 0.67 & 263.00 \\
\hline & 436 & 100 & 0.37 & 1.30 & 0.68 & 264.18 \\
\hline & 441 & 101 & 0.36 & 1.65 & 0.73 & 270.06 \\
\hline & 446 & 70 & 0.34 & 1.44 & 0.72 & 268.89 \\
\hline & 452 & 101 & 0.28 & 1.04 & 0.58 & 252.40 \\
\hline & 455 & 100 & 0.52 & 1.17 & 0.76 & 273.60 \\
\hline \multirow[t]{5}{*}{ Sanjiang Basin } & 302 & 103 & 0.63 & 2.05 & 1.01 & 303.04 \\
\hline & 305 & 101 & 0.54 & 1.52 & 1.04 & 306.57 \\
\hline & 310 & 100 & 0.59 & 2.07 & 1.24 & 330.12 \\
\hline & 311 & 100 & 0.60 & 1.90 & 0.94 & 294.79 \\
\hline & 313 & 101 & 0.70 & 2.06 & 1.04 & 306.57 \\
\hline \multirow[t]{24}{*}{ Erlian Basin } & 201 & 105 & 0.34 & 1.00 & 0.64 & 259.47 \\
\hline & 203 & 97 & 0.62 & 1.88 & 1.02 & 304.22 \\
\hline & 204 & 102 & 0.28 & 2.08 & 1.05 & 307.75 \\
\hline & 205 & 102 & 0.38 & 1.67 & 0.86 & 285.37 \\
\hline & 206 & 101 & 0.42 & 2.06 & 1.03 & 305.39 \\
\hline & 207 & 100 & 0.40 & 2.07 & 1.05 & 307.75 \\
\hline & 208 & 101 & 0.59 & 2.07 & 1.06 & 308.93 \\
\hline & 209 & 100 & 0.63 & 2.06 & 1.22 & 327.77 \\
\hline & 210 & 105 & 0.44 & 1.36 & 0.71 & 267.71 \\
\hline & 211 & 103 & 0.31 & 1.17 & 0.68 & 264.18 \\
\hline & 212 & 100 & 0.57 & 1.36 & 0.88 & 287.73 \\
\hline & 213 & 100 & 0.43 & 2.06 & 0.93 & 293.62 \\
\hline & 214 & 101 & 0.43 & 1.86 & 0.83 & 281.84 \\
\hline & 215 & 101 & 0.53 & 1.73 & 0.78 & 275.95 \\
\hline & 216 & 104 & 0.36 & 1.95 & 0.80 & 278.31 \\
\hline & 217 & 101 & 0.53 & 1.64 & 0.99 & 300.68 \\
\hline & 218 & 101 & 0.38 & 1.58 & 0.65 & 260.64 \\
\hline & 219 & 67 & 0.40 & 1.01 & 0.59 & 253.58 \\
\hline & 220 & 102 & 0.61 & 2.07 & 1.24 & 330.12 \\
\hline & $14-1^{*}$ & I & / & 2.10 & 1.30 & 337.19 \\
\hline & $14-2^{*}$ & I & I & 2.80 & 2.00 & 419.62 \\
\hline & $14-3^{*}$ & / & / & 2.90 & 1.30 & 337.19 \\
\hline & $11-1^{*}$ & I & / & 3.00 & 2.00 & 419.62 \\
\hline & $11-2^{*}$ & / & / & 1.20 & 1.10 & 313.64 \\
\hline
\end{tabular}

*Data from the Tengger Formation of Huolinhe sag in Erlian Basin (Xu 2011)

${ }^{* *} T=184.10+117.76 \times \%$ Ro (Jones 1997) 

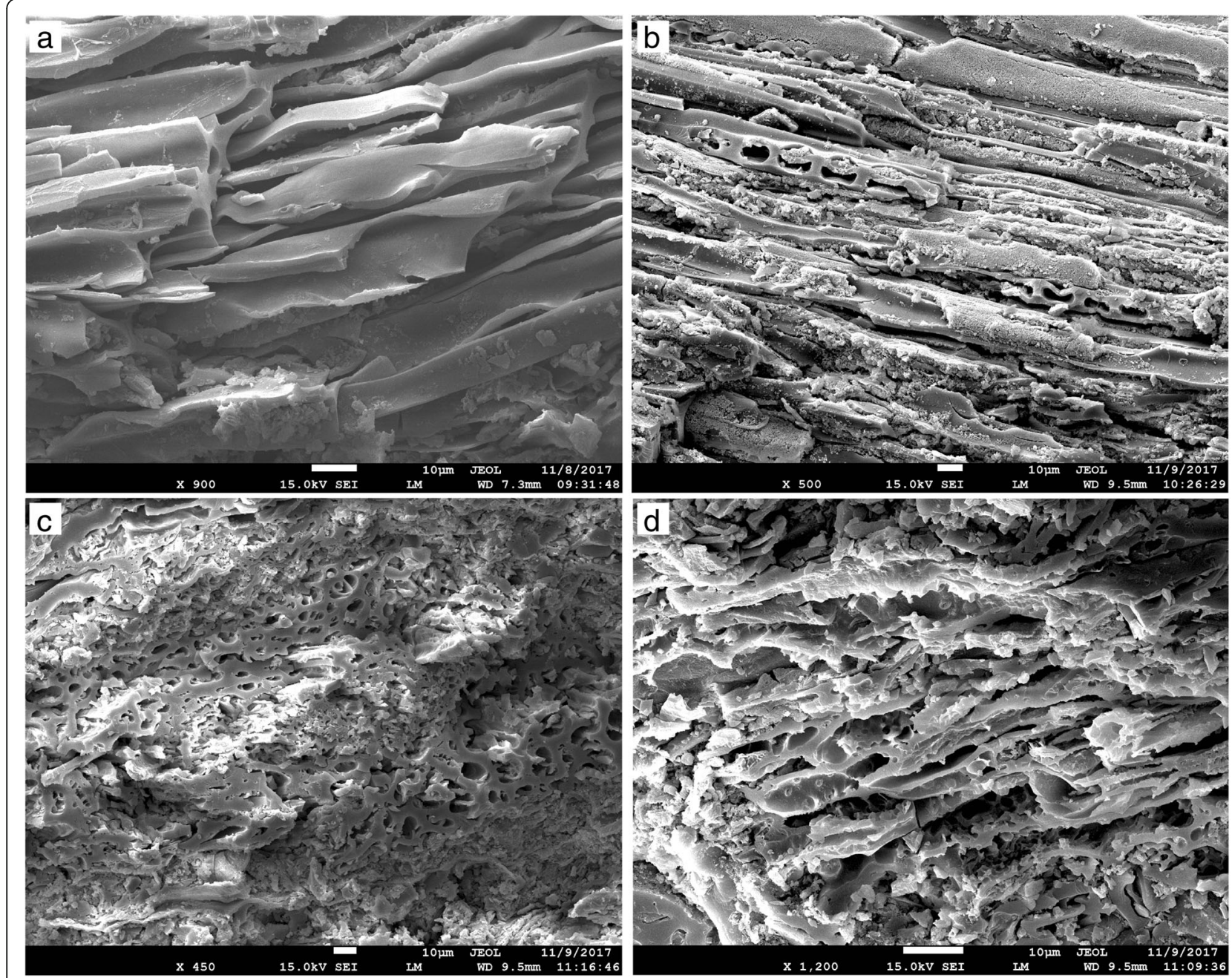

Fig. 4 Scanning electron microscope micrographs of inertinite in the studied coals. Fusinite, one of the major maceral types in the inertinite group, shows structured and homogenized cell walls, indicating a wildfire origin. a Longitudinal section of fusinite shows fibrous structure. Sample 416, Yimin Formation, Hailar Basin; b Longitudinal section of fusinite shows fibrous structure and pitting. Sample 441, Yimin Formation, Hailar Basin; c Cross section of fusinite shows weakly deformed cellular pore in fusinite. Sample 455, Yimin Formation, Hailar Basin; d Cross section of fusinite shows deformed cellular pores in fusinite. Sample 455, Yimin Formation, Hailar Basin

the fire types during the Aptian and Albian. During the Aptian, most inertinite has a low reflectance $(0.94 \%-$ $1.30 \%)$ and burning temperature $\left(294.79-337.19^{\circ} \mathrm{C}\right)$, indicating that they are mainly derived from ground fire. Some inertinite has high-reflectance values suggesting that it was derived from high temperatures, partially reaching surface fires (Fig. 5b). Sporo-pollens in coals show that the vegetation in peatland was dominated by conifers (gymnosperms) (Xu 2011). During the Albian, all inertinite macerals have low reflectance $(0.58 \%-$ $1.24 \%$ ) and low burning temperature $\left(252.40-330.12^{\circ} \mathrm{C}\right)$, suggesting they were mainly derived from ground fire (Fig. 5a). Sporo-pollen assemblages in the coals indicate that the vegetation was dominated by conifers and ferns (pteridophytes) (Shen et al. 2018), which might feed the ground fire.

\subsection{Fires in the Early Cretaceous peatland and the} implications for atmospheric oxygen levels

The wildfire activity can be almost influenced by the changes in lighting, fuel type, temperature and moisture (Scott 2000; Belcher et al. 2010; Robson et al. 2015). Global climate patterns from the Early Cretaceous show a long-term greenhouse trend ( $\mathrm{Hu}$ et al. 2012). During the Early Cretaceous, global warming associated with increased atmospheric carbon dioxide levels is likely to have enhanced storm tracks and convective storms, leading to a likely increase in the frequency of lightning strikes and subsequent ignition of wildfires (Belcher et al. 2010).

The seasonality and intensity of precipitation affect groundwater level and moisture content of fuel, determining fire ignition and spread in peat swamp ecosystems (Usup et al. 2004; Yan et al. 2016). Fire combustion 

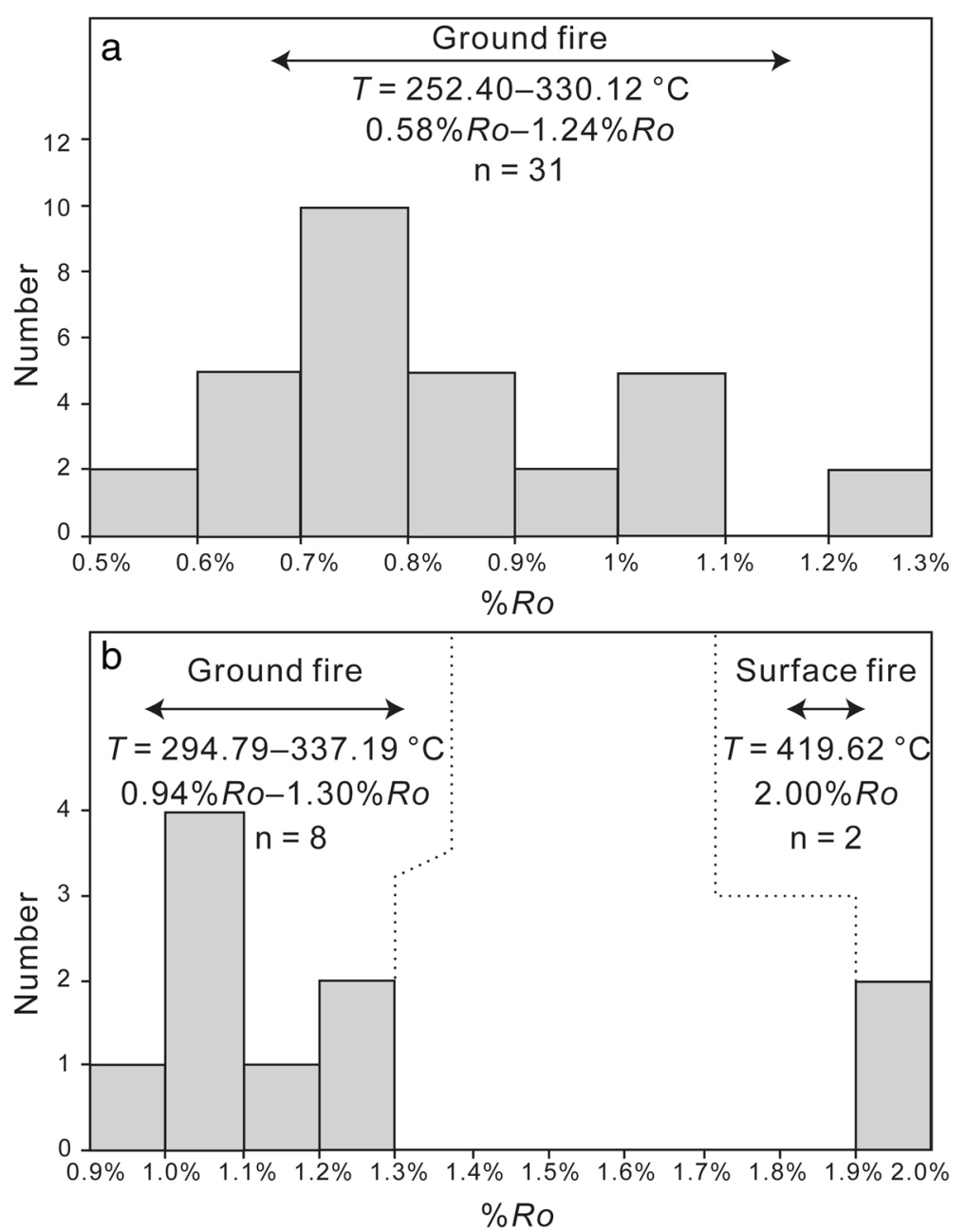

Fig. 5 Inertinite reflectance histograms showing calculated burning temperature $(T=184.10+117.76 \times \% R o)$ of selected reflectance intervals and the possible types. a Sample from the Saihantala and Yimin Formations corresponding to the Albian. All inertinite has low reflectance and low temperature suggesting that it was derived from ground fire; b Sample from the Tengger and Chengzihe Formations of the Aptian. 80\% inertinite of low reflectance and low temperature is interpreted to indicate that it was derived from ground fire, while $20 \%$ inertinite of high reflectance suggests that it was derived from high temperatures reached in surface fires. $n$ Number of samples

suggests low moisture content of fuels, which further indicates a low ground water level and lower air humidity (Yan et al. 2016). Increased rainfall will result in wetter fuel and be beneficial to plant growth. When coupled with increased temperatures and higher atmospheric oxygen levels, wetter plants will have more potential to burn, although they are previously difficult to ignite (Robson et al. 2015).

In addition to these factors, $\mathrm{O}_{2}$ is a key factor affecting the occurrence of wildfire. Based on the correlation model between inertinite content and atmospheric oxygen concentration $\left(p\left(\mathrm{O}_{2}\right)\right)$ (Glasspool et al. 2015), we have summarized the inertinite contents in the Aptian and Albian (about 22.6\% and 27.7\%, respectively), and then employed them to the established nonlinear fitting chart (Fig. 6). The result shows that $p\left(\mathrm{O}_{2}\right)$ levels of the Aptian and Albian during the Early Cretaceous in NE China are $24.7 \%$ and
$25.3 \%$ respectively, which exceeded the present atmospheric oxygen level of $21 \%$. Therefore, the records of inertinite, the large amounts of charred plant and the inferred high atmospheric oxygen levels suggest the Early Cretaceous was a high-fire period in NE China. The Early Cretaceous in NE China is an important period for the early evolution of angiosperms (Tao et al. 2013), so these results provide new information to provide context for this period of botanical innovation. In short, the earliest angiosperms were growing in elevated $\mathrm{O}_{2}$ conditions compared to the present day.

In addition to regional effects (Glasspool and Scott 2010), wildfires activity may also provide feedback towards promoting plant diversification and increasing greenhouse gas by releasing $\mathrm{CO}_{2}$ through combustion of biomass (Chanton et al. 2000; Bond and Scott 2010). Wildfire can lead to plant mortality, and the ability of a 


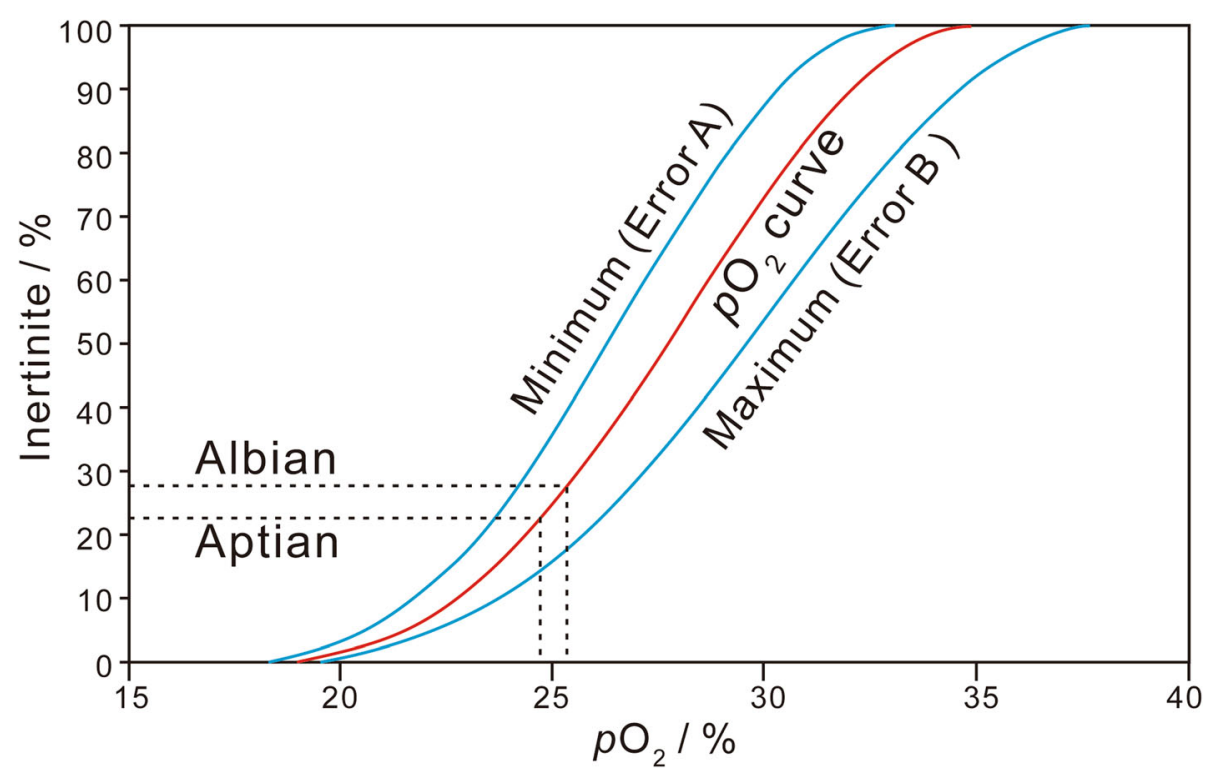

Fig. 6 Calculation of oxygen levels from the studied areas based on the model proposed by Glasspool et al. (2015). The oxygen curves have been calculated from the inertinite in coal data from Glasspool and Scott (2010) and Glasspool et al. (2015). S-shaped curves are assumed to ensure smooth transition from $0 \%$ inertinite to $100 \%$ inertinite of total macerals. Three curves represent the minimum, best and maximum estimate from left to right, respectively

plant to survive fire obviously determines the development of plant living in disturbed environments in a high-fire world (Brown et al. 2012; Shao et al. 2012). If frequent, fire may kill saplings of larger trees, consequently the herbaceous vegetation can be maintained (Bond and Keeley 2005). The herbaceous plant-fire cycle shows a competitive advantage during times of warmth and high $\mathrm{CO}_{2}$ and $\mathrm{O}_{2}$ (Bond and Scott 2010). Post-fire erosion is also an important factor having a major impact on Cretaceous terrestrial environments and may add phosphorous runoff into oceanic or lacustrine settings leading to anoxia and carbon burial (Brown et al. 2012). Therefore, the relationships between Lower Cretaceous charcoal assemblages, plant evolution, oxygen levels and anoxia events in Earth system should be further studied in order to reveal the palaeoenvironmental and palaeoecological information in the Lower Cretaceous coal-bearing strata.

\section{Conclusions}

1) Lower Cretaceous coals from NE China have been studied for their maceral compositions and inertinite reflectance. The results show that although macerals in the studied coals are generally dominated by huminite, inertinite contents are significant, ranging from $0.2 \%$ to $85.0 \%$, mostly within the range between $10 \%$ and $45 \%$.

2) The averaged inertinite contents in Aptian and Albian coals are around $22.6 \%$ and $27.7 \%$ respectively, indicating that wildfires were widely distributed in the Early Cretaceous coal-forming peatland.

3) Based on the relationship between burning temperature and inertinite reflectance, the burning temperature of palaeowildfire ranges from $252.40^{\circ} \mathrm{C}$ to $419.62^{\circ} \mathrm{C}$, suggesting that the palaeowildfire in the Aptian and Albian was dominated by ground fire.

4) Based on the established relationship between the palaeo-atmospheric $\mathrm{O}_{2}$ level and the inertinite content, the atmospheric oxygen contents of the Aptian and Albian were around $24.7 \%$ and $25.3 \%$ respectively.

5) These results support that the Cretaceous earliest angiosperms from $\mathrm{NE}$ China were growing in elevated $\mathrm{O}_{2}$ conditions compared to the present day.

\footnotetext{
Abbreviations

Co: Corpohuminite; Fu: Fusinite; GGG: Gadolinium galium garnet:

Id: Inertodetrinite; mmf: Mineral-matter-free (= no mineral matter); Ro: Reflectance in oil; Sf: Semifusinite; T: Temperature; UI: Ulminite; YAG: Yttrium alumimium garnet
}

\section{Acknowledgements}

We thank Jin-Yun Fan and Yu-Guo Kang for their assistance in sampling. We also thank the editor-in-chief, Zeng-Zhao Feng, editor Xiu-Fang Hu, reviewers Jason Hilton and Dieter Uhl for their constructive comments to improve the manuscript.

\section{Funding}

This research is funded by the National Science and Technology Major Project (2016ZX05041004-003), the Yue Qi Scholar Project of China University of Mining and Technology (Beijing), and the Central University Fundamental Research Fund (2010YD09). These funds help to the design of the study and collection, analysis, and interpretation of data. 


\section{Availability of data and materials}

All data generated or analyzed during this study are included in the manuscript.

\section{Authors' contributions}

SW carried out the data analysis and drafted the manuscript. LYS conceived the study and helped to revise the manuscript. ZMY participated in the design and coordination. MJS performed the experiment analysis. YHZ helped statistical analysis. All authors read and approved the final manuscript.

\section{Competing interests}

The authors declare that they have no competing interests.

\section{Publisher's Note}

Springer Nature remains neutral with regard to jurisdictional claims in published maps and institutional affiliations.

Received: 4 September 2018 Accepted: 1 March 2019

Published online: 30 April 2019

\section{References}

Belcher, C.M., L. Mander, G. Rein, F.X. Jervis, M. Haworth, S.P. Hesselbo, I.J. Glasspool, and J.C. McElwain. 2010. Increased fire activity at the Triassic/ Jurassic boundary in Greenland due to climate-driven floral change. Nature Geoscience 3 (6): 426-429.

Belcher, C.M., and J.C. McElwain. 2008. Limits for combustion in low $\mathrm{O}_{2}$ redefine paleoatmospheric predictions for the Mesozoic. Science 321 (5893): 1197-1200.

Bond, W.J., and J.E. Keeley. 2005. Fire as global 'herbivore': The ecology and evolution of flammable ecosystems. Trends in Ecology and Evolution 20 (7): 387-394

Bond, W.J., and A.C. Scott. 2010. Fire and the spread of flowering plants in the Cretaceous. The New Phytologist 188 (4): 1137-1150.

Bowman, D.M., J.K. Balch, P. Artaxo, W.J. Bond, J.M. Carlson, M.A. Cochrane, C.M. D'Antonio, R.S. Defries, J.C. Doyle, S.P. Harrison, F.H. Johnston, J.E. Keeley, M.A. Krawchuk, C.A. Kull, J.B. Marston, M.A. Moritz, I.C. Prentice, C. I. Roos, A.C. Scott, T.W. Swetnam, G.R. van der Werf, and S.J. Pyne. 2009. Fire in the Earth system. Science 324 (5926): 481-484.

Brown, S.A.E., A.C. Scott, I.J. Glasspool, and M.E. Collinson. 2012. Cretaceous wildfires and their impact on the Earth system. Cretaceous Research 36 (2): 162-190

Chanton, J.P., C.M. Rutkowski, C.C. Schwartz, D.E. Ward, and L. Boring. 2000. Factors influencing the stable carbon isotopic signature of methane from combustion and biomass burning. Journal of Geophysical Research: Atmospheres 105 (D2): 1867-1877.

Diessel, C.F.K. 2010. The stratigraphic distribution of inertinite. International Journal of Coal Geology 81 (4): 251-268.

Gao, Y.Q., L. Liu, and W.X. Hu. 2009. Petrology and isotopic geochemistry of dawsonite-bearing sandstones in Hailaer Basin, northeastern China. Applied Geochemistry 24 (9): 1724-1738.

Glasspool, I.J., D. Edwards, and L. Axe. 2004. Charcoal in the Silurian as evidence for the earliest wildfire. Geology 32 (5): 381-383.

Glasspool, I.J., and A.C. Scott. 2010. Phanerozoic concentrations of atmospheric oxygen reconstructed from sedimentary charcoal. Nature Geoscience 3 (9): 627-630.

Glasspool, I.J., A.C. Scott, D. Waltham, N. Pronina, and L.Y. Shao. 2015. The impact of fire on the Late Paleozoic Earth system. Frontiers in Plant Science 6: 756. https://doi.org/10.3389/fpls.2015.00756.

Guo, B., L.Y. Shao, J. Hilton, S. Wang, and L. Zhang. 2018. Sequence stratigraphic interpretation of peatland evolution in thick coal seams: Examples from Yimin Formation (Early Cretaceous), Hailaer Basin, China. International Journal of Coal Geology 196: 211-231.

Hamad, A.M.B.A., B. Amireh, H. El Atfy, A. Jasper, and D. Uhl. 2016. Fire in a Weichselia-dominated coastal ecosystem from the Lower Cretaceous (Barremian) of the Kurnub Group in NW Jordan. Cretaceous Research 66: 82-93.

Han, D.X., and Q. Yang. 1980. Coalfield Geology of China (Volume II). Beijing: China Coal Industry Press (in Chinese).
Heilongjiang Bureau of Geology and Mineral Resources. 1993. Regional Geology of Heilongjiang Province. Beijing: Geological Publishing House (in Chinese).

Hu, X.M., M. Wagreich, and I.O. Yilmaz. 2012. Marine rapid environmental/climatic change in the Cretaceous greenhouse world. Cretaceous Research 38: 1-6.

Hudspith, V., A.C. Scott, M.E. Collinson, N. Pronina, and T. Beeley. 2012. Evaluating the extent to which wildfire history can be interpreted from inertinite distribution in coal pillars: An example from the Late Permian, Kuznetsk Basin, Russia. International Journal of Coal Geology 89: 13-25.

ICCP (International Committee for Coal and Organic Petrology). 2001. The new inertinite classification (ICCP system 1994). Fuel 80 (4): 459-471.

ICS (International Commission on Stratigraphy). 2017. International Chronostratigraphic Chart: International Commission on Stratigraphy. http://www.stratigraphy.org/ICSchart/ChronostratChart2017-02.pdf. Accessed 15 May 2017.

Jasper, A., D. Agnihotri, R. Tewari, R. Spiekermann, E.F. Pires, Á.A.S. Da Rosa, and D. Uhl. 2017. Fires in the mire: Repeated fire events in Early Permian 'peat forming' vegetation of India. Geological Journal 52 (6): 955-969.

Jones, T.P. 1997. Fusain in Late Jurassic sediments from Witch Ground Graben, North Sea, U.K. Mededelingen Nederlands Instituut voor. Toegepaste Geowetenschappen TNO 58: 93-103.

Jones, T.P., and W.G. Chaloner. 1991. Fossil charcoal, its recognition and palaeoatmospheric significance. Palaeogeography, Palaeoclimatology, Palaeoecology 97 (1-2): 39-50.

Li, S.T. 1988. Fault Basin Analysis and Coal Accumulation. Beijing: Geological Publishing House (in Chinese).

Petersen, H.I, and S. Lindström. 2012. Synchronous wildfire activity rise and mire deforestation at the Triassic-Jurassic boundary. PLOS ONE 7 (10): e47236.

Petersen, H.I., and B. Ratanasthien. 2011. Coal facies in a Cenozoic paralic lignite bed, Krabi Basin, southern Thailand: Changing peat-forming conditions related to relative sea-level controlled watertable variations. International Journal of Coal Geology 87 (1): 2-12.

Robson, B.E., M.E. Collinson, W. Riegel, V. Wilde, A.C. Scott, and R.D. Pancost. 2015. Early Paleogene wildfires in peat-forming environments at Schöningen, Germany. Palaeogeography, Palaeoclimatology, Palaeoecology 437: 53-62.

Scott, A.C. 1989. Observations on the nature and origin of fusain. International Journal of Coal Geology 12: 443-475.

Scott, A.C. 2000. The Pre-Quaternary history of fire. Palaeogeography, Palaeoclimatology, Palaeoecology 164 (1): 281-329.

Scott, A.C. 2010. Charcoal recognition, taphonomy and uses in palaeoenvironmental analysis. Palaeogeography, Palaeoclimatology, Palaeoecology 291 (1): 11-39.

Scott, A.C., and I.J. Glasspool. 2006. The diversification of Paleozoic fire systems and fluctuations in atmospheric oxygen concentration. Proceedings of the National Academy of Sciences of the United States of America 103 (29): 10861-10865.

Scott, A.C., and I.J. Glasspool. 2007. Observations and experiments on the origin and formation of inertinite group macerals. International Journal of Coal Geology 70 (1): 53-66.

Scott, A.C., and T.P. Jones. 1994. The nature and influence of fire in Carboniferous ecosystems. Palaeogeography, Palaeoclimatology, Palaeoecology 106: 91-112.

Scott, A.C., and R. Stea. 2002. Fires sweep across the Mid-Cretaceous landscapes of Nova Scotia. Geoscientist 12: 4-6.

Sha, J.G. 2007. Cretaceous stratigraphy of northeastern China: Non-marine and marine correlation. Cretaceous Research 28: 146-170.

Shao, K., L.Y. Shao, Y.L. Qu, Q. Zhang, J. Wang, D. Gao, D.D. Wang, and Z. Li. 2013. Study of sequence stratigraphy of the Early Cretaceous coal measures in northeastern China. Journal of China Coal Society 38 (Supp. 2): 423-433 (in Chinese with English abstract).

Shao, L.Y., H. Wang, X.H. Yu, J. Lu, and M.Q. Zhang. 2012. Paleo-fires and atmospheric oxygen levels in the latest Permian: Evidence from maceral compositions of coals in eastern Yunnan, southern China. Acta Geologica Sinica (English Edition) 86 (4): 949-962.

Shen, J., Y. Qin, J.Y. Wang, Y.L. Shen, and G. Wang. 2018. Peat-forming environments and evolution of thick coal seam in Shengli Coalfield, China: Evidence from geochemistry, coal petrology, and palynology. Minerals 8 (3): 82. https://doi.org/10.3390/min8030082. 
Sun, G., and S.L. Zheng. 2000. New proposal on division and correlation of Mesozoic from northeastern China. Journal of Stratigraphy 24 (1): 60-64 (in Chinese with English abstract).

Sun, Y.Z., C.L. Zhao, W. Püttmann, W. Kalkreuth, and S.J. Qin. 2017. Evidence of widespread wildfires in a coal seam from the Middle Permian of the North China Basin. Lithosphere 9 (4): 595-608.

Sýkorová, I., W. Pickel, K. Christanis, M. Wolf, G.H. Taylor, and D. Flores. 2005. Classification of huminite-ICCP System 1994. International Journal of Coal Geology 62 (1): 85-106.

Tao, M.H., Z.Q. Cui, and G.Q. Chen. 2013. Mesozoic sporo-pollen assemblages and climate fluctuations in northeastern China. Acta Micropalaeontologica Sinica 30 (3): 275-287 (in Chinese with English abstract).

Uhl, D., and H. Kerp. 2003. Wildfires in the Late Palaeozoic of Central Europe The Zechstein (Upper Permian) of NW-Hesse (Germany). Palaeogeography, Palaeoclimatology, Palaeoecology 199 (1): 1-15.

Usup, A., Y. Hashimoto, H. Takahashi, and H. Hayasaka. 2004. Combustion and thermal characteristics of peat/forest fire in a tropical peatland in Kalimantan, Indonesia. Tropics 14 (1): 1-19.

Wang, C.S. 2013. Environmental/climate change in the Cretaceous greenhouse world: Records from terrestrial scientific drilling of Songliao Basin and adjacent areas of China. Palaeogeography, Palaeoclimatology, Palaeoecology 385: 1-5.

Wang, P.J., X.A. Xie, M. Frank, Y.G. Ren, D.F. Zhu, and X.M. Sun. 2007. The Cretaceous Songliao Basin: Volcanogenic succession, sedimentary sequence and tectonic evolution, NE China. Acta Geologica Sinica (English Edition) 81 (6): 1002-1011.

Wu, F.Y., D.Y. Sun, W.C. Ge, Y.B. Zhang, M.L. Grant, S.A. Wilde, and B.-M. Jahn. 2011. Geochronology of the Phanerozoic granitoids in northeastern China. Journal of Asian Earth Sciences 41 (1): 1-30.

Xu, Y. 2011. Early Cretaceous Paleowildfire in Huolinhe Coalfield of Eastern Inner Mongolia [PhD thesis]. Jilin University, Jilin Province, China (in Chinese with English abstract).

Yan, M.X., M.L. Wan, X.Z. He, X.D. Hou, and J. Wang. 2016. First report of Cisuralian (Early Permian) charcoal layers within a coal bed from Baode, North China with reference to global wildfire distribution. Palaeogeography, Palaeoclimatology, Palaeoecology 459: 394-408.

Yang, X.P., Y.C. Li, Z. Liu, Y. Wang, and H.J. Wang. 2005. Classification of tectonic sequence and dynamic evolution of Jixi Basin, eastern Heilongiiang Province. Journal of Jilin University (Earth Science Edition) 35 (5): 616-621 (in Chinese with English abstract).

Zhan, C.L., J.J. Cao, Y.M. Han, and Z.S. An. 2011. Research progress on reconstruction of paleofire history. Advances in Earth Science 26 (12): 1248-1259 (in Chinese with English abstract).

Zhang, C.J., and Y.W. Long. 1995. Sedimentary Facies Characteristics and Oil Gas Distribution of Hailar Basin. Beijing: Petroleum Industry Press (in Chinese).

Zhang, R., S. Dai, M.Z. Zhang, J. Zhao, L.B. Wang, L.L. Zhang, X. Zhang, and H.J. Liu. 2014. Early Cretaceous paleo-wildfire events recorded on the Wulan section in the Urat Back Banner of Inner Mongolia, China. Acta Geological Sinica 88 (6): 211-220 (in Chinese with English abstract).

Zhang, S.G., Y.B. Zhang, and H.J. Yan. 2015. Introduction to the Stratigraphic Chart of China (2014). Journal of Stratigraphy 39 (4): 359-366 (in Chinese with English abstract).

Zhang, X.Q., G.Q. Zhang, S.N. Xi, L.Q. Li, C.T. Deng, Y. Wang, N. Zhou, Y.D. Wang, and Y. Song. 2016. Wildfire event at the Triassic/Jurassic boundary: Approaches, progress, and perspective. Acta Palaeontologica Sinica 55 (3): 331-345 (in Chinese with English abstract).

Zhu, Y.H., W.H. Zhang, H.S. Wang, Z.Q. Cui, H.Y. Li, and C.Y. Han. 2000. Sedimentary Facies and Oil Bearing of the Lower Cretaceous in the Erlian Basin. Beijing: Science Press (in Chinese).

\section{Submit your manuscript to a SpringerOpen ${ }^{\circ}$ journal and benefit from:}

- Convenient online submission

- Rigorous peer review

- Open access: articles freely available online

- High visibility within the field

- Retaining the copyright to your article

Submit your next manuscript at $\boldsymbol{\nabla}$ springeropen.com 